\title{
Egy romániai magyar virtuális nyelvatlasz címszó-egyesítési kérdéseiről ${ }^{*}$
}

1. A romániai magyar nyelvjárások atlasza szerkesztői munkacsoportjában szinte a kezdetektől (1994-töl) jelen voltam, és többször is hangsúlyoztam publikációimban (HEGEDÜs 2002: 120, 2004: 178), milyen fontos lenne megteremteni a nyelvatlaszok hatékonyabb felhasználhatóságának lehetőségét, mert bár egyegy nyelvatlasz megjelenése önmagában is örvendetes esemény a dialektológusok körében, a bennük rejlő kutatási lehetőségek kiaknázása messze van az optimálistól. Arról is írtam, mi minden lehet az oka annak, hogy a gyüjtők és szerkesztők sokszor heroikus munkája révén létrejött nyelvatlaszok nem kerültek be kellő mértékben a nyelvtudomány vérkeringésébe (HEGEDÜs 2004: 178, 2008: 1-3, 7).

Az egyik oka, amiért a nyelvatlaszok nyomtatott kiadványokként nem eléggé kihasználtak, hogy önmagukban léteznek, azaz bár létezett a táji nyelvatlaszok gyüjtésének kezdetekor elképzelés arról, hogy összehangolt munkával az évek, évtizedek során egymással összevethető nyelvföldrajzi munkák készüljenek (VÉGH 1959: 52), ez a terv nem valósult meg maradandóan. (Az okok összegyüjtése és ismertetése minden bizonnyal fontos és érdekes adalék lehetne a szakemberek számára.) Valójában azért sem alakult ki úgynevezett központosított címszólekérdezési terv, mert különböző régiókat, nyelvjárási területeket sokszor más és más nyelvjárási jellegzetességek határoznak meg, így nagyon nehéz lett volna egy kötelező formulát adni a különböző gyüjtők számára.

Azaz kis túlzással elmondható, hogy ahány atlasz, annyi címszóstruktúra, és ez jelentősen hátráltatja az atlaszok adatainak összevethetőségét, pedig öszszevetésük hasznos lehet a nyelvtudomány számára, hiszen az egyes nyelvjárási területeken a nyelvi különbözőségek mellett sok a közös kifejezés, a közös nyelvi jellegzetesség is.

A nyelvatlaszok adatainak összehasonlításához nagyon fontos ezért, hogy a különböző kötetekben egymáshoz illeszthetö, azonos denotátumra vonatkozó térképlapok egymás „mellé” vagy „,egymásra” helyezhetők legyenek, és ehhez az eltéró címszóval rendelkező, de valójában azonos denotátumra vonatkozó térképlapokról kiderüljön, hogy ugyanannak a nyelvi valóságnak az adatait tartalmazzák.

2. Egyik nagyobb lélegzetü munkámban azoknak a nyelvatlaszoknak a virtuális adategyesítési terveiről írtam, amelyek a romániai magyar nyelvterületről készültek, és ehhez a kutatáshoz elkészítettem a romániai magyar nyelvterületen kutatópontokkal rendelkező atlaszok címszó-egyesítését (HEGEDÜs 2008: 165-280), vagyis A magyar nyelvjárások atlasza (MNyA.), A romániai magyar nyelvjárások

*Az Egy elkészült és egy készülő magyar nyelvatlasz - kutatási tapasztalatok és perspektívák című konferencián 2011. november 23-án elhangzott előadás szerkesztett, bővített változata.

Magyar Nyelv 112. 2016: 164-172. DOI: 10.18349/MagyarNyelv.2016.2.163 
atlasza (RMNyA.), a Szilágysági nyelvatlasz (SzilA.), a Hétfalu nyelvjárási atlasza (HétfA.), A moldvai csángó nyelvjárás atlasza (CsángA.), valamint a Székely nyelvföldrajzi szótár (SzNySz.) címszóanyagából egyesített címszólistát. ${ }^{1}$ (Bár a Székely nyelvföldrajzi szótár nem atlasz, címszóanyaga szótárként is alkalmas volt arra, hogy kutatásomhoz felhasználjam.) A címszóegyesítés során számos problémával kerültem szembe, meglepetésemre ugyanis egyáltalán nem volt mechanikus munka, hanem nagy körültekintést igényelt, és világossá vált számomra, hogy a problémák tipizálhatók. Ezeket pontokba szedtem (HEGEDÜs 2008: 17-29).

Vagyis az alábbi, sokszor nem is nyelvészeti problémákkal kellett megbírkózni ahhoz, hogy a romániai magyar nyelvjárásokról készült, nyomtatásban is megjelent nyelvatlaszok címszóanyagából egyesített címszólistát tudjak készíteni.

2.1. Helyesírási bizonytalanságok. Számos esetben a több tagú közös címszavak az egyik gyüjteményben szóösszetételként, a másikban pedig szókapcsolatként szerepelnek, a helyes alak eldöntésében a helyesírási szótárak segítettek (elsősorban az Osiris Helyesírás, másodsorban az Magyar helyesírási szótár), ha azok nem, akkor az Értelmező kéziszótár és egyes tájszótárak (Új magyar tájszótár, regionális tájszótárak). Példa: A tisztaszoba helyes alakja csak az ÚMTsz.-ból deríthető ki.

Kizárólag helyesírási hiba esetén javítottam a címszót megjegyzés, utalás nélkül.

2.2. Ha két különböző, de a köznyelvben egyenrangú variánsnak minősíthető címszóval találkoztam, az ún. „nagyobb atlasz” elve alapján döntöttem a valódi címszó és az utaló címszó kiválasztásáról, vagyis a nagyobb földrajzi területet vizsgáló atlasz címszava lett a valódi címszó. Például a disznó egyes szám harmadik személyü birtokos személyjeles adatait tartalmazó térkép disznója címszó alatt szerepel az MNyA.-ban és disznaja címszó alatt az RMNyA.-ban, de mivel az MNyA. nagyobb földrajzi területet mutat be, mint az RMNyA., így az MNyA. címszava lett a valódi címszó, és a disznaja az utaló. A tetvek $\approx$ tetük kettős változatú címszavak közül pedig a tetük lett a valódi címszó, a tetvek pedig utaló, mivel a tetvek csak egy atlasz (HétfA.) címszava, a tetük pedig az MNyA. és az RMNyA.-ban is ebben az alakban szerepel címszóként.

2.3. Egy kicsit más a probléma ebben a pontban, bár a 2.2. ponthoz kapcsolódik. Ha nem teljesen azonos a két címszó jelentése, vagyis nem egyenrangú variánsai egymásnak, oly módon, hogy az egyik pontatlanabb kifejezése a nyelvi valóságnak, akkor a pontosabbat választottam valódi címszónak. Például a félkarú (az RMNyA.-ból) és a félkezü (a CsángA.-ból) címszavak közül a félkarú lett a címszó, egyrészt mert nem azt fejezik ki az adatai, hogy a 'kezének csak a fele van meg', hanem azt, hogy 'az egyik karja hiányzik', másrészt azért is, mert a „nagyobb atlasz elve" alapján az RMNyA. címszavát kell választani. A kocsioldal címszó helyett pedig, amely utaló címszó lett a listában, szekéroldal a valódi címszó, mivel a kocsioldal címszó rosszul fejezi ki a tárgyat, ugyanis nem kocsinak, hanem szekérnek egy részére vonatkozik. A kertre néző szoba címszó pedig az ún.

${ }^{1}$ A feldolgozás nem tartalmazza a 2012-ben megjelent, romániai kutatópontokat is magában foglaló következő kiadványt: P. LAKATOS ILONA szerk., Változó nyelvhasználat a hármas határ mentén. Többdimenziós nyelvföldrajzi térképlapok tanúságai. Segédkönyvek a nyelvészet tanulmányozásához 146. Tinta Könyvkiadó, Budapest. 
lakószobára vonatkozik, amiben a falusi életmódot folytató családok az életüket élték (míg az ún. tisztaszobában senki sem lakott), ezért a kertre néző szoba utal a címszólistában a lakószoba valódi címszóra.

2.4. A 2.2. pontban szereplö szabály csak azokra az esetekre vonatkozik, amikor a címszók a köznyelvben is kétféle variánsban léteznek. Abban az esetben, ha a kétféle címszó közül az egyik a köznyelvben használatos (erre vonatkozóan köznyelvi szótárak adnak útmutatást, pl. Értelmező kéziszótár), a másik pedig a nyelvjárásokban, akkor a köznyelvi címszó lesz egyértelműen a lista valódi címszava. Például a 'valamin kívül' értelmü künn (a CsángA.-ban) és a kint (az RMNyA.-ban) ugyanazon valóságelemet mutatja be adataival. A künn lett az utaló címszó és a kint a valódi címszó, két fő ok miatt: 1 . Az Értelmező kéziszótár a kint-et jelzi köznyelvinek, 2. a „nagyobb atlasz elve” alapján az RMNyA. a követendő. Ugyanebbe a kategóriába tartozik a fenyőlevél utaló és a fenyőtü valódi címszó, mivel a fenyötü a köznyelvben is ismert szóalak, a fenyólevél pedig tájnyelvi kifejezés. A mégy és a mész esetén is ez a helyzet: a mégy-ből utaló lett, a mész lett a valódi címszó, mivel ez a köznyelvi változat.

2.5. Előfordul néhány eset, hogy két atlasz közül a kisebb területet bemutatóé pontosabb meghatározással adja meg a címszót, mint a nagyobb atlaszé, ilyenkor nem él a „nagyobb atlasz elve”, hanem a pontos meghatározás a fontosabb szempont. Például a csúszkál a jégen, a csúszkál (a jégen) és a csúszkál címszavak közül azért az RMNyA. címszava lett a valódi címszó, mert bár a „nagyobb atlasz elve" szerint az MNyA. csúszkál címszava lett volna a valódi, pontosítani kellett a valódi jelentés megadásához, hiszen nem a csúszkálás általános jelentésére vonatkozott a kérdés, hanem a jégen történő csúszkálás lexikai realizációit mutatja a térképlap. Az MNyA.-ban található, utaló címszóvá váló pirított kenyér a kisebb atlaszban, az RMNyA.-ban szereplő pirítós kenyér valódi címszavára utal, ez a példa is ebbe a csoportba tartozik.

2.6. Mind a grammatikai, mind a jelentésbeli homonímia esetén indexeléssel különítettem el az alakokat egymástól, és amikor tehettem, zárójeles megjegyzésben vagy értelmezőjelbe téve pontosítottam a címszót, illetve amikor nem volt egyértelmü, mire vonatkozott, megjegyzés nélkül, 1-es indexszámmal láttam el, és a pontosítatlant követték a jelentésüket megjegyzéssel körülhatárolt címszavak. Például ének1 és ének2 (egyházi). A megjegyzés nélküli ének valószínüleg általános jelentésben használatos, mivel nincs rá vonatkozóan semmilyen pontosítás, így ez a címszó kapta az 1-es indexet. Ebbe a csoportba tartozik az árpa1, árpa2 (gabonaféleség) és az árpa3 (szembetegség) címszavak is, az első címszó megjegyzés nélküli, és a hétfalusi atlaszból származik, a másik kettő pedig a nagyatlasz és A romániai magyar nyelvjárások atlaszának (is) a címszava, helyenként megjegyzéssel körvonalazva a jelentést. Szintén jó példa erre a kategóriára a pipa1 és a pipa2 (az ajtósaroké), mindkét címszó az RMNyA.-ban szerepel, az első a leggyakoribb jelentésre ('eszköz, amibe a dohányt tesszük') utal pontosító megjegyzés nélkül.

2.7. Bizonyos esetekben a térképlap eredeti címszava nem tüntet fel megjegyzést, külön értelmezést, én mégis megtettem ezt a listában, mert külön pontosítás nélkül teljesen más értelmet tulajdonítanánk a térképlapnak. Persze számos esetben a pontosítást zárójeles megjegyzéssel az atlasz is megteszi címszavában. 
Például agy (a keréké). Eredetileg csak agy volt a címszó, de mivel általános érvényű az emberi szervre vonatkozó jelentése, indokoltnak tartottam a zárójeles megjegyzést. Szintén jó példa itt az eredetileg megjegyzés nélküli író. Ezt a címszót pontosítani kellett a „(tejtermék)” értelmezéssel a címszólistában, mivel ellenkező esetben a használók elsőként minden bizonnyal a címszó leggyakoribb, mủvészi foglalkozásra vonatkozó jelentésére gondolnának.

2.8. Némely esetben viszont feltüntet a címszó után pontosító megjegyzést a kötet szerkesztője, pedig indokolatlan, mert megjegyzés nélkül is érthető a címszó jelentése. Ilyenkor utalások nélkül lehagytam a megjegyzést a címszó mellől. Például a CsángA.-ban földhöz (vágtam) alakban szerepel a földhöz címszó.

2.9. Amikor indokolt a szófaji minősítés, azt a lexikográfiában használatos jelölésekkel, zárójelben teszem. Indokoltnak akkor minősül, ha azonos alakú párja más szófajjal szintén szerepel a listában, vagy akkor is, ha bár azonos alakban más címszó nem szerepel a listában, mégis létezik homonimaként ilyen szó, és szófaji minősítés nélkül félreérthetö. Például a szelek igei funkcióban szerepel az RMNyA.-ban, nincs azonos alakú, főnévi párja az atlaszokban, de mivel a homonímia zavarhatja a keresést, pontosítottam „(ige)” megjelöléssel. A szán (fn) és a nevet (ige) alakok után pedig szintén tettem szófaji minősítést, mivel mindkettő rendelkezik homonimákkal: a szán igeként, a nevet pedig tárgyragos fönévként is él a köznyelvben.

2.10. Az azonos alakú, alanyi (általános) és tárgyas (határozott) ragozású igéket is indexeléssel és kiegészítéssel különböztetem meg, például enném1 (alanyi r.) és enném2 (tárgyas r.), valamint az innám1 (alanyi r.) és innám2 (tárgyas r.), továbbá a varrnátok2 (alanyi r.) és a varrnátok3 (tárgyas r.). (A varrnátok1 címszó esetén, amely a CsángA. III. kötetében található meg, nem lehet kideríteni, hogy alanyi vagy tárgyas ragozású igealakokat vonultat fel, ezért megjegyzés nélkül, egyes számú indexeléssel szerepel a listában.)

2.11. Amikor kettôs címszó van, vagyis két különböző grammatikai forma is szerepel egyetlen térképlapon, akkor két külön címszóval különböztettem meg őket a listában, és mindkettőhöz feltüntettem a megfelelő oszlopban a térképlapok pontos lelőhelyét. Például a Sándorhoz/-ékhoz címszó a SzilA.-ban: két valódi címszót alkottam belőle (Sándorhoz és Sándorékhoz), és mindkét címszó mellett feltüntettem a lelöhelyét. Megjegyzendö, hogy ezen a térképlapon 'Sándorhoz' és 'Sándorékhoz' jelentésben is szerepelnek adatok, de nem minden egyes kutatóponton, vagyis egyes kutatópontokon egyénre vonatkozó adatok is vannak és csoportra vonatkozók is, máshol meg vagy csak egyénre vonatkozók, vagy több személyre vonatkozók. Összesen három ilyen címszó van a SzilA.-ban, a következők: Sándorhoz/-ékhoz, Sándornál/-éknál, Sándortól/-éktól.

2.12. Számos esetben egy térképlapon két különböző címszó szerepel, hol egymás szinonimájaként (a SzilA.-ban), hol két különböző, de egymással öszszefüggő denotátum megjelenítéseként (ez a HétfA.-ban fordul elö). A szinonimaként szereplö címszavak közül az egyiket tartottam meg valódi címszóként (az eddig felsorolt szempontok alapján), a másik utalóként szerepel. Például az alvég, alszeg a SzilA. címszava. Alvég lett az utaló, mert csak egy atlasz címszava, és alszeg a valódi címszó, mert négy atlaszban megtalálható. (Az ilyen térképlapokból látszik, hogy bizonyos mértékig akár történhettek is egyeztetések 
a gyűjtések elött a különböző gyűjtők között.) További jó példa itt a Szilágysági nyelvatlasz orozva maró, alattomos (kutya) címszava, az orozva maró (kutya) lett a valódi címszó, mert ez a címszó a Szilágysági nyelvatlaszban és a Hétfalusi nyelvatlaszban is megtalálható; szintén megemlíthető itt a szalonnás, sületlen (kenyér) ismét a SzilA.-ból: a szalonnás (kenyér) lett a valódi címszó, a sületlen (kenyér) pedig az utaló, mert a Székely nyelvföldrajzi szótárban is megtalálható a szalonnás (kenyér) címszó.

2.13. Előfordul a két címszavú, szinonimákat címszóként szerepeltető térképlapok esetén, hogy egyik címszó sem marad meg, mert mindkét címszót egy harmadik címszó alá kellett sorolni egyrészt szerkezeti okok miatt (valójában a címszó egy indexekkel elválasztott „homonimaegyüttes” egyik tagja), másrészt az utalószóvá minősített variánsok szaknyelvinek tekinthetők. Például az SzNySz.-ben szereplő belsőség, beltelek címszó mindkét tagja utal a telek3 (földterület, építési terület) címszóra. A telek1 beépítetlen földterületre vonatkozik, a telek2 beépítettre, a telek4 pedig egészen más jelentéskörhöz tartozik (az ostor egyik része). Hasonló a helyzet a kályha1 (amivel föznek) és a kályha2 (amivel fütenek) címszavakkal a listában, amelyek valójában nem mindig így szerepelnek az atlaszokban: pl. a kályha1 a SzilA.-ban fútő, sütő tüzhely, főző́kályha címszóként szerepel.

2.14. Különböző keresztnevek becéző alakjai különböző címszavú térképeken szerepelnek. Például Gyuri és György (becealakjai): Gyuri lett az utaló és György (becealakjai) a valódi címszó, a Kati utaló címszó lett, a Katalin (becealakjai) pedig valódi címszóvá vált, vagy a Pista és az István (becealakjai) esetén szintén ez a helyzet.

2.15. A minőségjelzős szóösszetételek esetében az összetett szót átalakítottam értelmét megjegyzéssel pontosító egytagú szóra akkor, ha ezt egyéb körülmények is igénylik. Például a CsángA. szerepelteti agyagcsupor és bádogcsupor címszókkal, az RMNyA. pedig cserépcsupor címszóval az 'agyagból és bádogból készült csuprok' jelentésủ kifejezéseket, de csupor címszó is szerepel a SzilA.ban és a SzNySz.-ban, anyagának meghatározása nélkül. Azért, hogy a különféle csuprok nyelvi leképeződéseinek összevethetőségét elősegítsem, az agyag-, bádog- és cserépcsupor címszavakat „közelebb helyeztem” a csupor címszóhoz, indexeléssel és megjegyzésekkel: csupor1 - a megjegyzés nélküli változatok; csupor2 (bádogból), csupor3 (cserépből). Ha a csupor2 (bádogból) és a csupor3 (cserépből) címszavak adatai kizárólag szóösszetételként jelentkeztek volna, tehát az agyagcsupor, bádogcsupor és cserépcsupor fonetikai változatai szerepeltek volna a térképeken, akkor meghagytam volna az agyagcsupor, bádogesupor és cserépcsupor címszókat.

2.16. A felszólító módú alakokat sok atlasz nem jelöli, némely atlasz időnként jelöli, időnként nem, de csak zárójeles megjegyzéssel. Én egységesen elhagytam a zárójeles kiegészítéseket, és felkiáltójellel jelöltem a felszólító módú igealakokat, például: egyél!, jöjj!, nézz!

2.17. Vannak olyan címszavak a CsángA.-ban, amelyek más kötetben nem fordulnak elö, mert csak arra a nyelvjárási régióra jellemző a vizsgált nyelvi jelenség, és nincs köznyelvi megfelelöjük. Ilyenkor meghagytam az atlasz által szerepeltetett nyelvjárási alakot, például aluvál, aluvám, aluvék; az említett atlasz III. 
kötetében szereplő deberke magyar köznyelvi értelmezés nélküli címszó, szintén itt fordul elö magyar köznyelvi értelmezéssel néhány helyi változat is címszóként, pl. cepusa 'karó'.

2.18. Néhány esetben ún. „kombinált” címszót ad meg a CsángA. 3. kötete (BODÓ-VARGHA 2007), az adatok alapján táji alakot alkottak a gyüjtők, illetve szerkesztők, és annak köznyelvi megfelelőjét is. Ilyenkor a köznyelvi megfelelő lett a valódi címszó, annak ellenére, hogy az adatok között nincs szerepeltetve. Például eredetileg nem ura 'tud' menni a címszó, nem tud menni alakban került a listába.

2.19. Szintén a CsángA. 3. kötetében (BODÓ-VARGHA 2007) szerepel az a furcsa címszótípus, hogy a térképlapon szereplő mindkét szóalak köznyelvi megfelelője benne foglaltatik a címszóban. Ezt a címszót meghagytam: Ki volt/járt itt?

2.20. Néhány esetben román kölcsönszóval adja meg a CsángA. a címszót, mivel nincs rá pontos magyar köznyelvi megfelelö. Ilyen esetekben a „A magyar nyelvjárások román kölcsönszavai" címü kötetben szereplő címszavak segítettek a döntésben: maradjon-e az atlasz által megadott címszó, vagy szerepeljen helyette másik, például tyeptár 'bőrmellény'. Mivel sajátos csángó népviseletre utal, nem azonos a köznyelvi börmellény kifejezéssel, ezért maradt meg így a listában. Ellenpéldaként tüntetem itt fel a CsángA. timpla 'halánték' címszavát, amit bevontam a halánték alá, mert bár a timpla minden adata e lexéma fonetikai változataként jelentkezik, jelentése egyértelmủen azonosítható a köznyelvi halánték-éval. És mivel egyébként is szerepel más atlaszok címszavaként is a halánték, indokolt felülbírálni a CsángA.-ban feltüntetett címszót.

2.21. A bab, kukorica, búza, gabona, szőlő haszonnövények részeinek címszavait a következőképpen egységesítettem a jelölésben, pl. tő (a kukoricáé), illetve töve (a kukoricának), tekintettel arra, hogy a térképlap tőalakot és toldalékolt formát is bemutathat. Több gyüjtésben címszóként megtalálható a kukoricaszár neve aszerint, hogy a marha lerágta, hogy leszáradt-e már vagy zölden virít. A nagyatlaszban az „egytagú szó + megjegyzés” a címszók szerkezete, az RMNyA.-ban összetett szavakkal található meg a címszó. Így az egyenetlenséget a következőképpen küszöböltem ki, pl. a kukoricaszár (szárazon) utal a szár5 (a kukoricáé, szárazon) címszóra, a kukoricaszár (zölden) pedig a szár6 (a kukoricáé, zölden)-re.

2.22. Néhány esetben két külön sorban adtam meg a címszót, vagyis külön sorban, ha a szókapcsolatnak csak az egyik alakja jelenik meg az adatokban, és ismét külön sorban, ha az egész szókapcsolat is megjelenik. Például a borjas (tehén) és borjas tehén, vagy a veszett (kutya) és veszett kutya címszavak.

2.23. Az állathangutánzók mellett csak akkor szerepel az állat neve megjegyzésként, amikor az állathangutánzó ige nem egyértelműen egy bizonyos állatfaj hangadását adja vissza. Például bőg (a tehén), visít (a malac), vonít (a kutya), de a dorombol és a csiripel megjegyzés nélkül, mivel dorombolni csak a macska szokott, csiripelni a veréb.

2.24. Előfordul olyan eset, amikor úgy kell megváltoztatni a címszót, hogy bár semmilyen más atlaszban nem található meg, a „köznyelvi alak szerepeltetése” elv alapján indokolt egy új lexémát választani. Például fúvok a címszó a HétfA.ban, de ez utaló lesz, és fújok a valódi címszó, mivel van már fújom (a tüzet) az RMNyA.-ban. (Részben a „nagyobb atlasz elve” is indokolja a címszó ilyen 
köznyelviesítését.) Szintén ide tartoznak a borjúk és borjak címszavak, a borjúk az MNyA. címszava, de utaló lett a listában, a valódi címszó pedig a borjak, mert az RMNyA.-ban is szerepel ebben az alakban. Szintén ebbe a csoportba tartozik a HétfA. búvik címszava, amely utaló címszóvá vált, a valódi címszó pedig a bújik lett, ismét azért, mert az RMNyA.-ban ebben az alakban már előfordul.

3. Az imént részletezett, 24 pontból álló lista remélhetőleg elég jól szemlélteti, milyen sokféle körülményre kellett figyelemmel lenni a rendszerezéskor, egységesítéskor. Ez a lista hat nyelvatlasz összes címszavának a feldolgozása során jött létre. Valószínü, hogy újabb atlaszok térképlapjainak a rendszerbe illesztése során növekszik majd a pontok száma, és módosulhat a szempontrendszer is. Tudomásom szerint az én kísérletem óta legalább kétféle címszó-egyesítéssel próbálkoztak, amelyek valamilyen mértékben kapcsolódtak az általam összeállított munkához. Az egyik az RMNyA. utolsó, 11. kötetéhez kapcsolt címszó-egyesítés (RMNyA. 11: 605-637): ez a lista kizárólag az RMNyA. 11 kötetében szereplö címszavak listáját adja meg. A másik SZABÓ PANNA doktorandusz hallgató szakdolgozatában (az egyesített lista SZABÓ 2010: 90-171, az egyesítés problematikája: uo. 34-57, összefoglalóan SzABÓ 2012) található. Ő az általam kialakított szempontokat alapul véve dolgozta ki saját címszó-egyesítését, amikor a nyugati magyar nyelvterületen kiadott nyelvatlaszok címszavai alapján állította össze a listáját. E módszertant alapul véve a magyar nyelvterületről mostanra 24 nyelvatlasz egységes szempontok szerint egyesített címszójegyzékének mutatója készült el (1. SZABÓ 2015).

Véleményem szerint a fentiekben bemutatott tipológia lefedi azokat problémákat, amelyek a magyar nyelvjárási atlaszokban megtalálható címszavak egyesítéséhez kapcsolódnak. Ez azt jelenti, hogy bár a jövőben megjelenő atlaszok címszavai módosíthatnak majd a címszó-egyesítési rendszeren, ez már valószínüleg csak a részleteket fogja érinteni, a rendszer alapjait nem.

Kulcsszók: atlaszegyesítés, utaló címszó, valódi címszó, egyesített címszójegyzék, nyelvatlasz, nyelvföldrajz.

\section{Hivatkozott irodalom}

Bodó CSANÁD - VARgha FrUzSINA SÁRA 2007. Jelenségtérképek a moldvai csángó nyelvjárás atlaszából. [Megjelent CD-n.] ELTE Magyar Nyelvtörténeti, Szociolingvisztikai, Dialektológiai Tanszék, Budapest.

CsángA. = A moldvai csángó nyelvjárás atlasza. $1-2$. Szerk. GÁlfFy MózeS - MÁRTON GYULA - SZABÓ T. ATTILA. Magyar Nyelvtudományi Társaság, Budapest, 1991.

Deme LÁsZló - FÁBiÁn PÁL - Tóth ETELKA szerk. 1999. Magyar helyesírási szótár. Akadémiai Kiadó, Budapest.

HEGEDÜS ANDREA 1998. Nyelvföldrajzi vizsgálatok a romániai magyar nyelvterületen, különös tekintettel az egyesitett atlaszok lehetöségeire. Szakdolgozat. ELTE BTK, Budapest. 
HEGEDÜS ANDREA 2002. Nyelvjárási atlaszok egyesítési lehetőségei. In: SzABÓ GÉZA MolnÁr Zoltán - Guttmann Miklós szerk., IV. Dialektológiai Szimpozion. Szombathely, 2001. augusztus 23-25. A Berzsenyi Dániel Tanárképző Főiskola Szombathely. 120-127.

HEGEDÜS ANDREA 2004. Az egyesített nyelvatlaszok jelentőségéről In: P. LAKATOS IlONA - T. KÁROLYI MARGIT szerk., Nyelvvesztés, nyelvjárásvesztés, nyelvcsere. Segédkönyvek a nyelvészet tanulmányozásához 32. Tinta Könyvkiadó, Budapest. $178-181$.

HEGEDÜS ANDREA 2008. Nyelvföldrajzi vizsgálatok a romániai magyar nyelvterületen az egyesitett atlaszok felhasználásával. Doktori (PhD) disszertáció. ELTE BTK, Budapest.

HétfA. = Hétfalu nyelvjárási atlasza. Szerk. VöÖ IsTVÁN. Babes-Bolyai Tudományegyetem, Kolozsvár, 1971.

LACZKÓ KRISZTINA - MÁRTONFi ATTILA 2004. Helyesírás. Osiris Kiadó, Budapest.

MNyA. = A magyar nyelvjárások atlasza 1-6. Szerk. DEME LÁSZLÓ - IMRE SAMU. Akadémiai Kiadó, Budapest, 1968-1977.

ÖHA. = VÉGH JÓZSEF 1959. Örségi és hetési nyelvatlasz. Akadémiai Kiadó, Budapest.

PUSZTAI FERENC szerk. 2003. Magyar értelmező kéziszótár. MTA Nyelvtudományi Intézete és Akadémiai Kiadó, Budapest.

RMNyA. = A romániai magyar nyelvjárások atlasza 1-11. Gyüjtötte és a kéziratot összeállította MURÁDIN LÁSZLÓ. Szerk. JUHÁSz DEZSŐ. [1-2.] Magyar Nyelvtudományi Társaság, [3-11.] Magyar Nyelvtudományi Társaság - Pharma Press Kiadó, Budapest, 1995-2010.

SzABÓ PANNA 2010. Az atlaszegyesités néhány kérdése a nyugati magyar nyelvterület dialektológiai atlaszai alapján. Szakdolgozat. ELTE BTK, Budapest.

SzABÓ PANNA 2012. Az atlaszegyesítés lexikográfiai-filológiai kérdései a nyugati magyar nyelvterület nyelvatlaszai alapján. In: PARAPATICS ANDREA - CSERNÁKSZUHÁNSZKY DEBÓRA szerk., Félúton 7. A hetedik Félúton konferencia (2011) kiadványa. ELTE BTK Nyelvtudományi Doktori Iskola, Budapest. SzP1-SzP15. http://[-] hdl.handle.net/10831/8267 (2016. 07. 26.)

SZABÓ PANNA 2015. Pillanatkép a nyelvatlaszok egyesítési háttérmunkálatainak állásáról. In: BÁRTH M. JÁNOS - BODÓ CSANÁD - KoCSIS ZsuZSANNA szerk., A nyelv dimenziói: Tanulmányok Juhász Dezsö tiszteletére. ELTE Magyar Nyelvtudományi és Finnugor Intézet - Magyar Nyelvtudományi Társaság, Budapest. 221-228.

SzilA. = Szilágysági nyelvatlasz. Gyüjt. MÁRTON GYULA, szerk. HEGEDüs ATTILA. A Pázmány Péter Katolikus Egyetem Magyar Nyelvészeti Tanszékének Kiadványai 3. Magyar Nyelvtudományi Társaság - PPKE, Piliscsaba-Budapest, 2000.

SzNySz. = Székely nyelvföldrajzi szótár. Összeáll. GÁLfFY MÓZES - MÁRTON GYULA, szerk. KISS JENÖ. Akadémiai Kiadó, Budapest, 1987.

ÚMTsz. = B. LŐRINCZY ÉVA föszerk. 1979-2010. Új magyar tájszótár 1-5. Akadémiai Kiadó, Budapest.

[VÖRÖSMARTY MihÁly - DÖBRETEI GÁBOR? szerk.] 1838. Magyar tájszótár. Magyar Tudós Társaság, Buda. 


\section{On issues of the merger of entries in a virtual language atlas of Hungarian dialects spoken in Romania}

This paper discusses the merger of entries of language atlases of Hungarian-speaking territories of Romania: A Linguistic Atlas of Szilágyság; two printed volumes of Atlas of Moldavian Csángó Dialects, and the third volume published in CD format only, A Dialect Atlas of Hétfalu; the Székely Linguistic Geography Dictionary; as well as The Atlas of Hungarian Dialects in Romania covering the whole Hungarian linguistic area in Romania and The Atlas of Hungarian Dialects that includes collection sites from Romania, too. It lists twenty-four typical lexicographic problems occurring during the process of merging entries, illustrating each problem by at least one but possibly two or three examples. The paper suggests that creating a table of merged entries required considerable circumspection; the table then served as a point of departure for listing the headwords of other regional linguistic atlases of the Hungarian-speaking area in an aggregate list of headwords, the work of a different researcher.

Keywords: linguistic geography, language atlas, merging of atlases, aggregate headword list, cross-referring entry, full entry.

HEGEDÜS ANDREA

BGSZC Fáy András Közlekedésgépészeti, Müszaki Szakközépiskolája 